\title{
Letter \\ Acute transient thyroid swelling after catheterization of the subclavian vein
}

\author{
R Arthur Bouwman ${ }^{1}$, Martijn R Meijerink² and Albertus Beishuizen ${ }^{3}$ \\ ${ }^{1}$ Department of Anesthesiology, VU University Medical Center, Amsterdam, the Netherlands \\ 2Department of Radiology, VU University Medical Center, Amsterdam, the Netherlands \\ ${ }^{3}$ Department of Intensive Care, VU University Medical Center, Amsterdam, the Netherlands
}

Corresponding author: R Arthur Bouwman, a.bouwman@vumc.nl

Published: 7 October 2009

This article is online at http://ccforum.com/content/13/5/419

(c) 2009 BioMed Central Ltd
Critical Care 2009, 13:419 (doi:10.1186/cc8032)

\section{Figure 1}

(a)

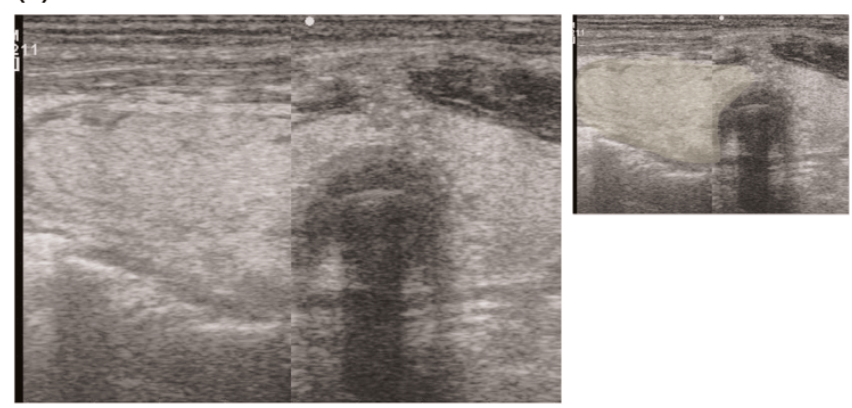

(b)

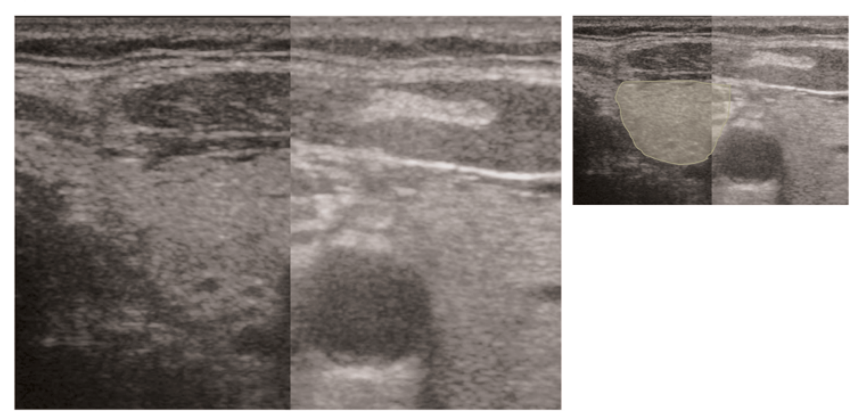

Acute generalized thyroid swelling that (a) developed shortly after a subclavian vein catheterization attempt and (b) spontaneously resolved after a few hours.

suggested that acute release of vaso-active substances, such as calcitonin gene-related peptide, leads to acute edema formation through vasodilation and capillary leak [4]. Previous reports have described thyroid swelling as being terrifying, but airway obstruction was not reported. We could not establish whether in our case swelling of the thyroid would have led to airway obstruction, as the patient's airway was secured.

pass into the thyroid gland. The mechanism of acute thyroid gland swelling remains speculative, but Bruel and colleagues 
(a)
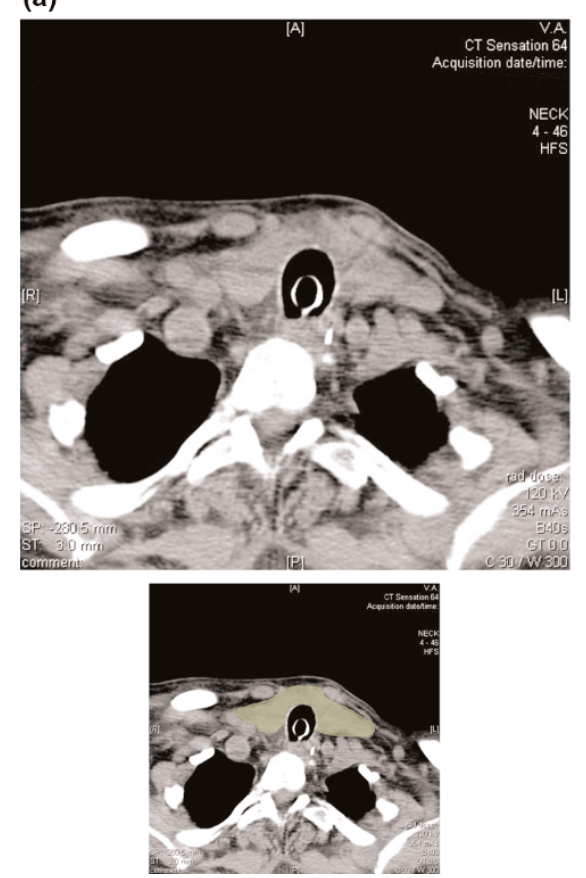

(b)
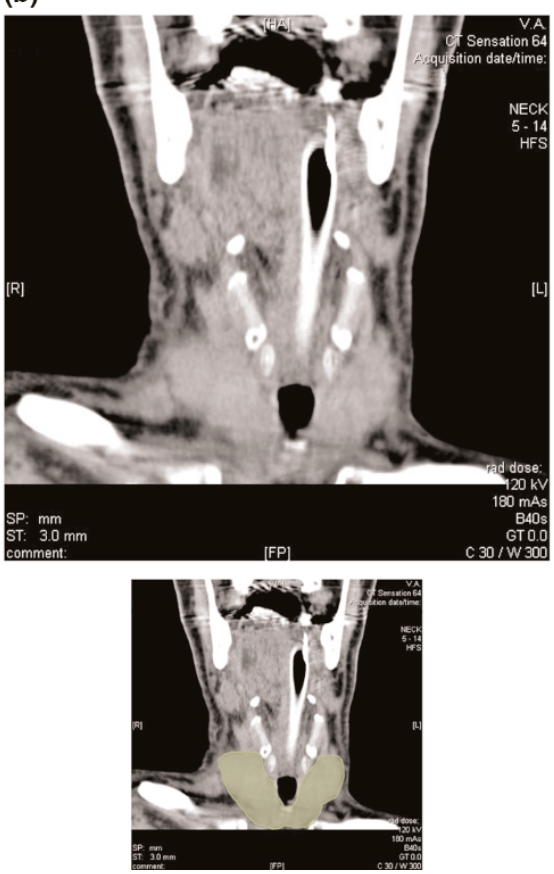

Computed tomography imaging of the neck. (a) Transverse and (b) reconstructed coronal computed tomography images of the thyroid gland showing the anatomical relationship between the enlarged thyroid and the puncture trajectory for subclavian vein catheterization. This suggests that inadvertent puncture of the thyroid gland could have occurred during subclavian vein catheterization.

In summary, we present a case of acute swelling of the thyroid gland as an unexpected complication after attempted subclavian vein catheterization. The extent of swelling was impressive, but resolved within hours without intervention.

\section{Competing interests}

The authors declare that they have no competing interests.

\section{Acknowledgements}

Written consent for publication was obtained from the patient's relatives.

\section{References}

1. McGee DC, Gould MK: Preventing complications of central venous catheterization. N Engl J Med 2003, 348:1123-1133.

2. Dal Fabbro S, Barbazza R, Fabris C, Perelli R: Acute thyroid swelling after fine needle aspiration biopsy. J Endocrinol Invest 1987, 10:105.

3. Haas SN: Acute thyroid swelling after needle biopsy of the thyroid. N Engl J Med 1982, 307:1349.

4. Van den Bruel A, Roelandt P, Drijkoningen M, Hudders JP, Decallonne B, Bouillon R: A thyroid thriller: acute transient and symmetric goiter after fine-needle aspiration of a solitary thyroid nodule. Thyroid 2008, 18:81-84.

5. Moore KL: The neck. In Clinically Oriented Anatomy. 3rd edition. Edited by Satterfield TS. Baltimore: Wiliams \& Wilkins; 1992:817820. 